\title{
D-6 FIRST RESULTS FROM THE MULTI-CHANNEL SEISMIC REFLECTION STUDY IN THE GULF OF MARMARIS
}

\author{
NESLIHAN OCAKOGLU', EMIN DEMIRBAG ${ }^{1}$, BERKAN ECEVITOGLU', \\ ISMAIL KUSCU ${ }^{2}$, CEMAL GOCMEN ${ }^{2}$ and SAHIN KARAGOZ 2 \\ 'Istanbul Technical University, Mining Faculty, Department of Geophysics, \\ 80626 Maslak /stanbul. Turkey \\ ${ }^{2}$ General Directorate of Mineral Research and Exploration
}

\begin{abstract}
Summary
The active tectonism in the Gulf of Marmaris located at the southwest Anatolia Region was investigated by means of multi-channel seismic reflection data.

In seismic lines, seabed bathymetry smoothly deeps from north to south. Prograted delta fronts of rivers are observed in the N-S sections. Two seismic units are marked: first one is the Lycian Nappes which form basement units and the second one is Plio-Quaternary sediments with a maximum thickness of $650 \mathrm{~m}$ on top of the Lycian Nappes. There are not active fault systems in the shelf area of the Gulf of Marmaris except a few N-S trending normal faults. These normal faults cut the sediments and can hardly be traced in the basement rocks. This is also confirmed by relatively less microseismic activity in the area.
\end{abstract}

\section{Introduction}

The purpose of this study is to investigate the structural features of the Gulf of Marmaris under the regional neotectonic regime in the Aegean Sea-Western Anatolia and furthermore to correlate the results with the onland tectonic frame.

On land geology, the Lycian Nappes, parallochthonous Lutetian-Priabonian and Lower Miocene rocks, neoautochthonous plutonic and volcanic rocks of Middle-Upper Miocene age, and PlioQuaternary rocks are exposed in the westernmost part of the Western Taurides, in the junction of the Aegean and Mediterranean areas. The Lycian Nappes consisting of the tectonostratigraphic units developed in different enviromental conditions are represented by Bodrum nappe, Gülbahar nappe and Marmaris ophiolite nappe from bottom to top in the region. The Lycian Nappes which assembled north of the Menderes Massif during the Late Senonian, where emplaced on and south of Menderes Massif during the Late Eocene as due to approximately N-S compression regime. The Lycian Nappes have been moved the further south and were emplaced on the Beydağları autochthon during the Lower Langhian (Şenel, 1997; Brunn et al., 1971).

According to earthquake solutions by Kalafat (1995) in the Marmaris Gulf and Rodos Basin which is a continuation of Crete island arc, thrust faults with small angles are observed with respect to the subduction of the lithosphere under the Aegean Sea and west Anatolia in Mediterranean. On land and in the gulf, relatively less microseismic activity is observed between $0-4$ magnitudes in the last 30 years. 


\section{Data acquisition and processing}

Multi-channel seismic reflection data were collected on nine lines (total of $380 \mathrm{~km}$ ) in the Gulf of Marmaris by MTA Seismic-1 research vessel. The processed line locations and general geology map in the study area are given in Figure 1. The energy source was a 10 gun source array with a volume of 1380 cubic inch, which is well enough to penetrate to a depth of a few kilometers. The number of channels 96 and 120. Receiver group interval, shot interval and near offset are $12.5 \mathrm{~m}, 50 \mathrm{~m}$ and $237.5 \mathrm{~m}$, respectively. These parameters provided minumum 12 fold common-depth-point (CDP) data. Sampling interval and record length are $2 \mathrm{~ms}$ and $5120 \mathrm{~ms}$. A conventional data processing stream was applied to data as follows: data transcription, in-line geometry definiton, shot-receiver static correction, editing, shot muting, gain correction, CDP sorting, velocity analysis, NMO correction, muting, stacking, band-pass filtering, post stack finite-difference time migration, automatic gain correction (AGC).

\section{Observations and Conclusions}

In seismic lines, there is smoothly deepening seabed from $120 \mathrm{~m}$ to approximately $375 \mathrm{~m}$ depth in N-S direction. Prograted delta fronts of rivers in surrounding land are well observed in Line1 (Fig. 2). In seismic line-3, deformed basement units called Lycian Nappes, which cover a large area in the Southwest-Anatolia, form a small graben structure. Lycian Nappes can be divided into two units in the area: a complex Lycian Nappes at the bottom and Peridotites Nappes at the top which is called Marmaris Ophiolite of Cretaceous age (Brunn et al.; 1971). At the eastern part of line-3, complex reflection structures and plutonic intrusion reflection patterns are observed. Also sea bottom is very ondulated at the easternmost. In seismic sections, PlioQuaternary aged deposits on top of the Lycian Nappes are seen with a maximum thickness of $650 \mathrm{~m}$. In line-3, probably N-S trending active normal faults are observed in the east and west side of the Gulf which cut upper deposits and rarely basement units (Fig. 2.). In general, there are less number of active faults deforming the sediments and basement units which is confirmed by relatively less microseismic activity in the gulf area.

\section{References}

- Brunn, J.H., Dumont, J.F., Graciansky, P. CH., Gutnic, M., Juteou, T., Marcoux, J., Monod, O., Poisson. A., 1971, Outline of the Geology of the Western Taurids, in: Geology and History of Turkey (Ed. A. S. Campbell, Petr. Expl. Soc. Libya, Tripoli), p. 225-255.

- Kalafat, D., 1995, The investigation of structural pattem of Turkey by earthquakes focal mechanism solutions, PhD. Thesis Department of Marine geology and geophysics, İstanbul.

- Şenel, M., 1997, 1:250 000 scaled, Geology maps of Turkey, Marmaris Section, No:1, MTA, Ankara. 

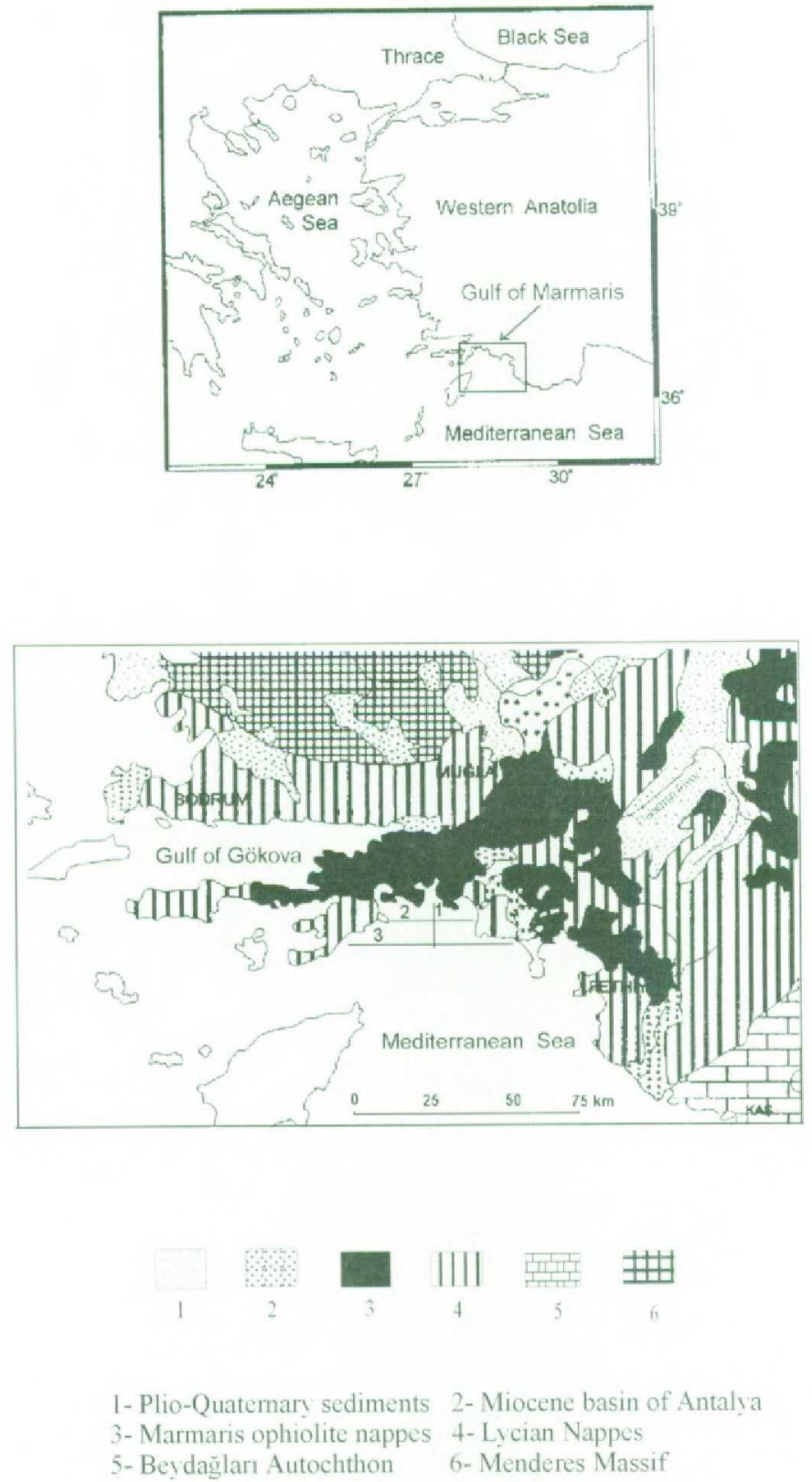

Fig. 1. Location map of the study area and the land geology map of the Marmaris area (modified from Senel: 1997). 




